\title{
YIELD AND QUALITY OF BLACK CUMIN (Nigella sativa L.) POPULATIONS: THE EFFECT OF ECOLOGICAL CONDITIONS
}

\author{
Nimet KARA ${ }^{1 *}$, Duran KATAR ${ }^{2}$, Hasan BAYDAR ${ }^{1}$ \\ ${ }^{1}$ Suleyman Demirel University, Faculty of Agriculture, Department of Field Crops, Isparta, TURKEY \\ ${ }^{2}$ Eskisehir Osmangazi University, Faculty of Agriculture, Department of Field Crops, Eskisehir, TURKEY \\ *Corresponding author: nimetkara@sdu.edu.tr
}

Received: 17.11.2014

\begin{abstract}
The experiment was carried out in two vegetation seasons of 2013 and 2014 at the Isparta and Eskisehir ecological conditions. The main purpose of the study was to determine the effects of years and locations on seed yield, some yield-related traits, essential oil content and fixed oil ratio of black cumin populations. In the study, black cumin populations were obtained from Burdur, Tokat, Usak, Eskisehir and Antalya provinces. The experiments were arranged according to a randomized complete-block design with three replications. The average seed yield varied between $201.0-407.1 \mathrm{~kg} \mathrm{ha}^{-1}$ in 2013 and 458.9-790.3 $\mathrm{kg} \mathrm{ha}^{-1}$ in 2014. In compared to locations; while yield components of black cumin populations significantly varied according to locations and years, seed yield in both years were higher in Isparta location on all populations due to higher rainfall than Eskisehir. In compared to populations; the highest seed yield was determined in Usak population and it was followed by Eskisehir population. But the essential oil wasn't detected in Usak population. The highest essential oil content was obtained from Tokat population in both locations and years, it was followed by Eskisehir population. The fixed oil ratios were higher in Tokat, Usak and Antalya populations in both locations and years.
\end{abstract}

Keywords: Black cumin, Yield, Essential oil, Fixed oil

\section{INTRODUCTION}

Black cumin (Nigella sativa L.) is a medicinal plant annual belonging to Ranunculacea family which grown naturally in Southwest Asia and the Mediterranean Region (Toncer and Kizil, 2004). Black cumin seeds contain protein, alkaloids (nigellicines and nigelledine), saponin ( $\alpha$ - hederin) fixed and essential oil (Ozel et al., 2009). The fixed and essential oil of black cumin contain various bioactive molecules such as thymoquinone, thymol, tocopherol, trans retinol and selenium (Sultan et al., 2009).

12 species of black cumin are naturally grown in Turkey's flora. The seeds of Nigella sativa, Nigella damascena and Nigella arvensis are used in folk medicine and as a spice. The black cumin is cultivated commonly in Afyon, Isparta, Burdur and Konya regions in Turkey (Baytop, 1984) and only the species of black cumin (Nigella sativa L.) is traded (Kar et al., 2007). Black cumin is intensively used in as uncrushed in bakery products (bread, muffins, biscuits, etc.) and in some cheese (brynza, cottage cheese, etc.) in Turkey (Akgul, 1993). However, the production is limited compared to many other crops and at the level that will correspond to a very little part of domestic consumption (Kar et al., 2007). Recently, industry facilities based on the evaluation of medicinal and aromatic plants in which included the black cumin. Industrialists emphasize that the demand to fixed oil of black cumin is much and so, the necessity of increasing local production for the supply of raw material (Yilmaz, 2008). For this reason, black cumin is a plant having potential in Turkey in the future. However, there is very little studies about adaptation and quality in our country and the studies are generally related to row spacing and fertilizing. Local population are generally used as seed production and breeding materials by breeders and farmers due to the lack of cultivars. Toncer and Kizil (2004) mentioned that seed yield in black cumin was 828 $\mathrm{kg} \mathrm{ha}^{-1}$ and essential oil content was between $0.27 \%$ and $0.35 \%$. Ozel et al. (2009) reported that seed yield in black cumin at $1406.3-2482.3 \mathrm{~kg} \mathrm{ha}^{-1}$, and essential oil content was at $0.24-0.43 \%$. Sener et al. (1985) detected that there was $0.26 \%$ lauric, $1.06 \%$ myristic, $20.4 \%$ palmitic, $1.56 \%$ stearic, $4.75 \%$ oleic, $64.6 \%$ linoleic and $7.18 \%$ arachidonic acid in fixed oil of black cumin. Nergiz and Otles (1993) stated that there was about 32\% oil in black cumin seeds. 
Climate and soil conditions that are the main factors on growth and development of the plants, the physiological growth of the plants, being synthesized of the active substances, the amount and quality of obtained essential oil. Especially, the effect of ecological factors on yield and essential oil of medicinal plants is higher compared to the other plants. Because the quality in medicinal and aromatic plants is as important as yield, the ones below a certain quality cannot be cultivated even if they are very high yield. Therefore, they should only be cultivated in the convenient regions for the ecologies of these plants (Yasar, 2005).

This study was conducted in order to determine the seed yield, some yield components, essential oil content and fixed oil rate of black cumin populations in Isparta and Eskisehir ecological conditions having different altitudes and climate conditions (especially rainfall) where black cumin cultivation is performed.

\section{MATERIALS AND METHODS}

\section{Experimental conditions}

The experiment was conducted during the growing seasons of 2013 and 2014 years at the Isparta and Eskisehir ecological conditions in Turkey. In this study, black cumin populations were used obtained from Burdur, Tokat, Usak, Eskisehir and Antalya because there is currently no black cumin cultivar registered in Turkey.

The province of Isparta located in the transition region in the inner part of the western Mediterranean region in between the Mediterranean Sea and the Central Anatolia Region bear the climate features (annual average rainfall is $524 \mathrm{~mm}$ ) of both of the regions with 1050 meters altitude. The province of Eskisehir located in Aegean, Marmara and Central Anatolia Region with 788 meters altitude has semi-arid (annual average rainfall is 349.8 $\mathrm{mm}$ ) and cool continental climate. Winter months are frosty and summer months are hot and the nights are cool. There are big differences between day and night temperatures.

The experiment land was plowed, cultivated and then prepared for planting with a single pass of a disk-harrow. The experiments were arranged according to a randomized complete-block design with three replicates. Seeds were sown by hand in the first week of March in the ratio of 15 $\mathrm{kg} \mathrm{ha}^{-1}$ in both the experimental years in Isparta location and were sown in the second week of March in both the experimental years in Eskisehir location. The distance between rows was $20 \mathrm{~cm}$ and with in the rows were $5 \mathrm{~cm}$. Each plot area was $7.2 \mathrm{~m}^{2}(6 \mathrm{~m} \times 1.2 \mathrm{~m})$ and consisted of 6 rows. Seeds were sowed at $1-2 \mathrm{~cm}$ depths using a dibbler.

Nitrogen and phosphorus fertilizers were applied at a rate of $60 \mathrm{~kg} \mathrm{ha}^{-1}$ and $40 \mathrm{~kg} \mathrm{ha}^{-1}$ in the form of ammonium sulphate and $\mathrm{P}_{2} \mathrm{O}_{5}$, respectively (Tuncturk et al., 2012).
The total quantity of phosphorus fertilizer was applied at the time of sowing. Total nitrogen fertilization was applied in two equal doses, at the time of sowing and plant height when $15 \mathrm{~cm}$. In both years and locations, the experiments were non-irrigated at any growing stage. All the necessary cultural practices were similarly applied to the plots during vegetation periods in both locations.

\section{Climatic data of the experimental locations}

Meteorological data for the growing seasons of locations are shown in Table 1. During the vegetative periods (from March to end of August) in 2013 and in 2014 a total precipitation of 289.5 and $284.2 \mathrm{~mm}$, average temperature of 20.6 and $19.7{ }^{\circ} \mathrm{C}$ and an average humidity of 61.0 and $66.1 \%$ were recorded in Isparta, a total precipitation of 122.9 and $143.6 \mathrm{~mm}$, average temperature of 16.7 and $16.6{ }^{\circ} \mathrm{C}$ and an average humidity of 55.6 and $61.8 \%$ were recorded in Eskisehir.

\section{Soil structure}

Soil at a depth of $60 \mathrm{~cm}$ was sampled before the experiment and subjected to a physicochemical analysis. Data for the years and locations are shown in Table 2.

\section{Yield and its components}

When the seeds ripen, plants from 4 rows in the center of each plot were harvested manually. Seed yield $\left(\mathrm{kg} \mathrm{ha}^{-1}\right)$ and its components including plant height $(\mathrm{cm})$, the number of branches (branches plant ${ }^{-1}$ ), the number of capsule (capsule plant ${ }^{-1}$ ) and 1000-seed weight $(\mathrm{g})$ were determined.

\section{Essential Oil Distillation}

In order to determine the seed essential oil content, $100 \mathrm{~g}$ powdered black cumin samples in $0.5 \mathrm{~L}$ water from each population were extracted by hydro-distilllation for 3 hours using Clevenger apparatus according to the standard procedure described in European Pharmacopoeia (Stainier, 1975) for determining the oil content (v/w, \%).

\section{Fixed Oil}

$4 \mathrm{~g}$ dried and powdered black cumin samples from each population were extracted with $n$-hexan for 6 hours using soxhlet apparatus (Buchi Universal Extraction System B-811, Germany) for determining the fixed oil content $(\%)$.

\section{Statistical Analysis}

All the data were analyzed according to the analysis of variance (ANOVA) using SAS Statistical Package Program, the significant differences between the group means were separated using the LSD (Least Significant Difference) test. 
Table 1. Meteorological data of the experiment locations*

\begin{tabular}{|c|c|c|c|c|c|c|c|c|}
\hline \multicolumn{9}{|c|}{ ISPARTA } \\
\hline \multirow{2}{*}{ Climatic factors } & \multirow{2}{*}{ Years } & \multicolumn{6}{|c|}{ Months } & \multirow{2}{*}{$\begin{array}{l}\text { Total or } \\
\text { Average }\end{array}$} \\
\hline & & March & April & May & June & July & August & \\
\hline \multirow{3}{*}{$\begin{array}{l}\text { Precipitation } \\
(\mathrm{mm})\end{array}$} & 2013 & 25.1 & 59.9 & 66.5 & 34.4 & 88.2 & 15.4 & 289.5 \\
\hline & 2014 & 78.6 & 44.8 & 107.0 & 42.8 & 0.8 & 10.2 & 284.2 \\
\hline & Long Years & 52.8 & 56.6 & 50.8 & 28.4 & 18.4 & 0.8 & 207.8 \\
\hline Average & 2013 & 7.2 & 11.9 & 17.1 & 20.5 & 23.0 & 23.7 & 20.6 \\
\hline \multirow{2}{*}{$\begin{array}{l}\text { Temperature } \\
\text { (i C) }\end{array}$} & 2014 & 7.2 & 11.0 & 14.5 & 19.1 & 23.7 & 23.2 & 19.7 \\
\hline & Long Years & 5.9 & 10.8 & 15.6 & 20.1 & 22.3 & 23.9 & 19.7 \\
\hline \multirow{3}{*}{$\begin{array}{l}\text { Relative } \\
\text { humidity } \\
(\%)\end{array}$} & 2013 & 60.0 & 58.0 & 52.0 & 50.0 & 44.0 & 41.0 & 61.0 \\
\hline & 2014 & 63.7 & 60.4 & 62.4 & 52.7 & 45.3 & 45.9 & 66.1 \\
\hline & Long Years & 61.3 & 64.2 & 50.3 & 53.0 & 45.8 & 44.5 & 63.8 \\
\hline \multicolumn{9}{|c|}{ ESKISEHIR } \\
\hline \multirow{2}{*}{ Climatic factors } & \multirow{2}{*}{ Years } & \multicolumn{6}{|c|}{ Months } & \multirow{2}{*}{$\begin{array}{l}\text { Total or } \\
\text { Average }\end{array}$} \\
\hline & & March & April & May & June & July & August & \\
\hline \multirow{3}{*}{$\begin{array}{l}\text { Precipitation } \\
(\mathrm{mm})\end{array}$} & 2013 & 40.1 & 30.9 & 18.5 & 31.3 & 2.1 & 0.0 & 122.9 \\
\hline & 2014 & 23.1 & 15.2 & 27.2 & 70.6 & 7.5 & 0.0 & 143.6 \\
\hline & Long Years & 27.6 & 43.1 & 40.0 & 23.7 & 13.1 & 9.2 & 156.7 \\
\hline \multirow{3}{*}{$\begin{array}{l}\text { Average } \\
\text { Temperature } \\
\text { (C) }\end{array}$} & 2013 & 7.1 & 10.8 & 18.2 & 20.0 & 21.6 & 22.4 & 16.7 \\
\hline & 2014 & 6.5 & 11.3 & 16.4 & 19.9 & 23.7 & 21.9 & 16.6 \\
\hline & Long Years & 4.9 & 9.6 & 14.9 & 19.1 & 22.1 & 21.8 & 15.4 \\
\hline \multirow{3}{*}{$\begin{array}{l}\text { Relative } \\
\text { humidity (\%) }\end{array}$} & 2013 & 59.8 & 63.2 & 51.5 & 53.9 & 51.9 & 53.1 & 55.6 \\
\hline & 2014 & 69.0 & 63.7 & 63.3 & 64.1 & 57.8 & 52.8 & 61.8 \\
\hline & Long Years & 64.2 & 62.7 & 59.5 & 55.2 & 51.9 & 53.6 & 57.9 \\
\hline
\end{tabular}

*Data were taken from Isparta and Eskisehir Regional Meteorological Service

Table 2. Physical and chemical characteristics of soil in experiment locations

\begin{tabular}{|c|c|c|c|c|c|c|}
\hline \multicolumn{7}{|c|}{ ISPARTA } \\
\hline Years & Structure & $\begin{array}{l}\text { Lime } \\
(\%)\end{array}$ & $\begin{array}{l}\text { Available } \\
\text { Phosphorus } \\
\left(\mathrm{P}_{2} \mathrm{O}_{5}\right)\left(\mathrm{kg} \mathrm{ha}^{-1}\right)\end{array}$ & $\begin{array}{l}\text { Available } \\
\text { Potassium } \\
\left(\mathrm{K}_{2} \mathrm{O}\right)\left(\mathrm{kg} \mathrm{ha}^{-1}\right)\end{array}$ & $\mathbf{p H}$ & $\begin{array}{l}\text { Organic } \\
\text { Matter (\%) }\end{array}$ \\
\hline 2013 & Clay-Loam & 10.79 & 9.61 & 705 & 8.1 & 1.69 \\
\hline 2014 & Clay-Loam & 9.62 & 9.00 & 650 & 7.9 & 1.38 \\
\hline \multicolumn{7}{|c|}{ ESKISEHIR } \\
\hline 2013 & Clay-Loam & $8 ., 57$ & 8.95 & 1290 & 7.71 & 1.58 \\
\hline 2014 & Clay-Loam & 7.13 & 6.69 & 1050 & 8.0 & 1.43 \\
\hline
\end{tabular}

\section{RESULTS AND DISCUSSION}

Seed yield, plant height, the number of branches, the number of capsule and 1000-seed weight of black cumin populations in Isparta and Eskisehir locations are presented in Table 3. In this research, differences among of years (except for 1000-seed weight, essential oil content and fixed oil rate), populations, locations (except for 1000-seed weight in loc II of the first year) and population $\mathrm{x}$ location interaction were found to be statistically significant for both years (Table 3).

\section{Seed yield}

Seed yields of black cumin populations varied according to locations and years. Mean seed yield in the second year $\left(576.0 \mathrm{~kg} \mathrm{ha}^{-1}\right)$ were higher than yield in the first year (291.9 $\left.\mathrm{kg} \mathrm{ha}^{-1}\right)$ Table 3). These differences resulted from higher rainfall in growing period of plant in the second year according to first year in both locations (Table 1).

In compared to locations, the mean seed yield in Isparta location was higher than Eskisehir location in both years. These differences in the mean seed yield could be explained by the higher rainfall in Isparta location (Table 1 and 3$)$.

In compared to populations, while the highest seed yield was determined in Usak population (626.3 and $940.3 \mathrm{~kg} \mathrm{ha}^{-1}$, respectively) in Isparta location in both years, in Eskisehir location the highest seed yield were obtained from Tokat population $\left(244.4 \mathrm{~kg} \mathrm{ha}^{-1}\right)$ in the first year and from Usak population $\left(640.3 \mathrm{~kg} \mathrm{ha}^{-1}\right)$ in the second year.

The average seed yield in population $x$ location interaction varied between 201.0-407.1 kg ha-1 during 2013 and 458.9-790.3 $\mathrm{kg} \mathrm{ha}^{-1}$ during 2014 (Table 3) 
Table 3. Yield, yield components, essential oil content and fixed oil rate of black cumin populations

\begin{tabular}{|c|c|c|c|c|c|c|c|c|c|c|c|c|}
\hline \multirow{3}{*}{$\begin{array}{c}\text { Populations } \\
/ \\
\text { Locations }\end{array}$} & \multicolumn{6}{|c|}{ Plant height $(\mathrm{cm})$} & \multicolumn{6}{|c|}{ Number of branches (branches plant ${ }^{-1}$ ) } \\
\hline & \multicolumn{3}{|c|}{2013} & \multicolumn{3}{|c|}{2014} & \multicolumn{3}{|c|}{2013} & \multicolumn{3}{|c|}{2014} \\
\hline & Loc I & Loc II & Average & Loc I & Loc II & Average & Loc I & Loc II & Average & Loc I & Loc II & Average \\
\hline Burdur & $22.7 \mathrm{~b}$ & $16.1 \mathrm{~d}$ & $19.4 \mathrm{c}$ & $33.5 \mathrm{bc}$ & $26.4 \mathrm{~b}$ & $29.9 \mathrm{~b}$ & $2.8 \mathrm{~b}$ & $2.4 \mathrm{~cd}$ & $2.6 \mathrm{~b}$ & $3.6 \mathrm{~b}$ & $4.4 \mathrm{ab}$ & $4.0 \mathrm{c}$ \\
\hline Tokat & $34.1 \mathrm{a}$ & $22.2 \mathrm{a}$ & $28.1 \mathrm{a}$ & $47.1 \mathrm{a}$ & $24.5 \mathrm{~b}$ & $35.8 \mathrm{a}$ & $3.7 \mathrm{ab}$ & $3.5 \mathrm{a}$ & $3.6 \mathrm{a}$ & $5.2 \mathrm{a}$ & $4.1 \mathrm{~b}$ & $4.6 \mathrm{ab}$ \\
\hline Usak & $28.7 \mathrm{ab}$ & $16.6 \mathrm{~cd}$ & $22.6 \mathrm{~b}$ & $30.9 \mathrm{c}$ & $26.0 \mathrm{~b}$ & $28.4 \mathrm{~b}$ & $4.4 \mathrm{a}$ & $2.7 \mathrm{bc}$ & $3.5 \mathrm{a}$ & $4.0 \mathrm{~b}$ & $5.0 \mathrm{a}$ & $4.5 \mathrm{~b}$ \\
\hline Eskisehir & $33.1 \mathrm{a}$ & $19.8 \mathrm{~b}$ & $26.4 \mathrm{a}$ & $44.1 \mathrm{ab}$ & $29.4 \mathrm{a}$ & $36.7 \mathrm{a}$ & $3.4 \mathrm{ab}$ & $2.0 \mathrm{~d}$ & $2.7 \mathrm{~b}$ & $5.3 \mathrm{a}$ & $4.5 \mathrm{ab}$ & $4.9 \mathrm{a}$ \\
\hline Antalya & $26.3 \mathrm{ab}$ & $17.8 \mathrm{c}$ & $22.0 \mathrm{~b}$ & $32.5 \mathrm{bc}$ & $25.8 \mathrm{~b}$ & $29.1 \mathrm{~b}$ & $3.9 \mathrm{ab}$ & $3.3 \mathrm{ab}$ & $3.6 \mathrm{a}$ & $4.1 \mathrm{~b}$ & $4.8 \mathrm{ab}$ & $4.5 \mathrm{~b}$ \\
\hline Mean & $29.0 \mathrm{~A}$ & $18.5 \mathrm{~B}$ & 23.7 B & $36.8 \mathrm{~A}$ & $26.0 \mathrm{~B}$ & 31.4 A & $3.6 \mathrm{~A}$ & $2.8 \mathrm{~B}$ & $3.2 \mathrm{~B}$ & 4.4 & 4.6 & $4.5 \mathrm{~A}$ \\
\hline $\mathrm{CV}$ & 9.95 & 2.82 & 8.72 & 12.65 & 3.71 & 10.73 & 12.05 & 9.56 & 8.57 & 4.88 & 6.21 & 5.60 \\
\hline Lsd & 7.90 & 1.43 & 2.53 & 13.04 & 2.69 & 4.20 & 1.19 & 0.73 & 0.732 & 0.59 & 0.77 & 0.31 \\
\hline F value & $8.10 *$ & $66.67 * *$ & $17.28 * *$ & $7.26 * *$ & $10.01 * *$ & $6.86^{*}$ & $4.66 *$ & $17.76^{* * *}$ & $4.61 *$ & $34.85 * *$ & $4.46^{*}$ & $21.73 * *$ \\
\hline \multirow{3}{*}{$\begin{array}{c}\text { Populations } \\
/ \\
\text { Locations }\end{array}$} & \multicolumn{6}{|c|}{ Number of capsule (capsule plant ${ }^{-1}$ ) } & \multicolumn{6}{|c|}{1000 seed weight $(\mathrm{g})$} \\
\hline & \multicolumn{3}{|c|}{2013} & \multicolumn{3}{|c|}{2014} & \multicolumn{3}{|c|}{2013} & \multicolumn{3}{|c|}{2014} \\
\hline & Loc I & Loc II & Average & Loc I & Loc II & Average & Loc I & Loc II & Average & Loc I & Loc II & Average \\
\hline Burdur & $3.6 \mathrm{~b}$ & $2.1 \mathrm{c}$ & $2.8 \mathrm{c}$ & $4.4 \mathrm{~b}$ & 3.36 & $3.88 \mathrm{c}$ & $2.95 \mathrm{a}$ & 2.63 & $2.79 \mathrm{a}$ & $2.84 \mathrm{a}$ & $2.80 \mathrm{a}$ & $2.82 \mathrm{a}$ \\
\hline Tokat & $5.7 \mathrm{ab}$ & $4.0 \mathrm{a}$ & $4.8 \mathrm{a}$ & $6.7 \mathrm{a}$ & 3.63 & $5.2 \mathrm{ab}$ & $2.12 \mathrm{~b}$ & 2.46 & $2.29 \mathrm{~b}$ & $2.10 \mathrm{c}$ & $2.73 \mathrm{ab}$ & $2.41 \mathrm{~b}$ \\
\hline Usak & $7.1 \mathrm{a}$ & $2.6 \mathrm{bc}$ & $4.9 \mathrm{a}$ & $7.7 \mathrm{a}$ & 3.80 & $5.7 \mathrm{a}$ & $3.14 \mathrm{a}$ & 2.60 & $2.87 \mathrm{a}$ & $2.91 \mathrm{a}$ & $2.10 \mathrm{c}$ & $2.50 \mathrm{~b}$ \\
\hline Eskisehir & $5.6 \mathrm{ab}$ & $2.2 \mathrm{bc}$ & $3.9 \mathrm{~b}$ & $7.2 \mathrm{a}$ & 3.81 & $5.5 \mathrm{a}$ & $2.49 \mathrm{ab}$ & 2.80 & $2.64 \mathrm{a}$ & $2.49 \mathrm{~b}$ & 2.40abc & $2.44 \mathrm{~b}$ \\
\hline Antalya & $6.1 \mathrm{ab}$ & $2.7 \mathrm{~b}$ & $4.4 \mathrm{ab}$ & $6.0 \mathrm{ab}$ & 3.70 & $4.8 \mathrm{~b}$ & $2.64 \mathrm{ab}$ & 2.76 & $2.70 \mathrm{a}$ & $2.50 \mathrm{~b}$ & $2.23 \mathrm{bc}$ & $2.37 \mathrm{~b}$ \\
\hline Mean & $5.6 \mathrm{~A}$ & $2.7 \mathrm{~B}$ & $4.1 \mathrm{~B}$ & $6.4 \mathrm{~A}$ & $3.6 \mathrm{~B}$ & $5.0 \mathrm{~A}$ & 2.67 & 2.65 & 2.66 & 2.57 & 2.45 & 2.51 \\
\hline $\mathrm{CV}$ & 7.77 & 7.85 & 11.31 & 10.41 & 8.02 & 10.4 & 10.50 & 7.93 & 9.31 & 4.33 & 8.04 & 6.38 \\
\hline Lsd & 2.73 & 0.56 & 0.88 & 1.82 & ns & 0.63 & 0.76 & ns & 0.30 & 0.30 & 0.54 & 0.19 \\
\hline F value & $4.85 *$ & $38.60 * *$ & $4.57 *$ & $10.99 * *$ & 1.11 & $6.98 *$ & $5.95 *$ & 1.23 & $3.74 *$ & $25.37 * *$ & $7.21 * *$ & $15.67 * *$ \\
\hline \multirow{3}{*}{$\begin{array}{c}\text { Populations } \\
/ \\
\text { Locations }\end{array}$} & \multicolumn{6}{|c|}{ Seed yields $\left(\mathrm{kg} \mathrm{ha}^{-1}\right)$} & \multicolumn{6}{|c|}{ Essential oil content (\%) } \\
\hline & \multicolumn{3}{|c|}{2013} & \multicolumn{3}{|c|}{2014} & \multicolumn{3}{|c|}{2013} & \multicolumn{3}{|c|}{2014} \\
\hline & Loc I & Loc II & Average & Loc I & Loc II & Average & Loc I & Loc II & Average & Loc I & Loc II & Average \\
\hline Burdur & $204.3 \mathrm{c}$ & $197.7 \mathrm{~b}$ & $201.0 \mathrm{~d}$ & $494.0 \mathrm{c}$ & $493.5 b c$ & $494.0 \mathrm{~cd}$ & $0.17 \mathrm{bc}$ & $0.14 \mathrm{c}$ & $0.15 \mathrm{c}$ & $0.15 \mathrm{c}$ & $0.11 \mathrm{~b}$ & $0.13 \mathrm{c}$ \\
\hline Tokat & $313.0 \mathrm{c}$ & $244.4 \mathrm{a}$ & $278.7 \mathrm{c}$ & $499.6 \mathrm{c}$ & $418.1 \mathrm{c}$ & $458.9 \mathrm{~d}$ & $0.50 \mathrm{a}$ & $0.78 \mathrm{a}$ & $0.64 \mathrm{a}$ & $0.48 \mathrm{a}$ & $0.66 \mathrm{a}$ & $0.58 \mathrm{a}$ \\
\hline Usak & $626.3 \mathrm{a}$ & $187.8 \mathrm{~b}$ & $407.1 \mathrm{a}$ & $940.3 \mathrm{a}$ & $640.3 \mathrm{a}$ & $790.3 \mathrm{a}$ & - & - & - & - & - & - \\
\hline Eskisehir & $468.3 \mathrm{~b}$ & $192.2 \mathrm{~b}$ & $330.3 \mathrm{~b}$ & $690.3 \mathrm{~b}$ & $558.5 \mathrm{ab}$ & $624.4 \mathrm{~b}$ & $0.33 \mathrm{ab}$ & $0.64 \mathrm{~b}$ & $0.48 \mathrm{~b}$ & $0.32 \mathrm{~b}$ & $0.57 \mathrm{a}$ & $0.44 \mathrm{~b}$ \\
\hline Antalya & $274.6 \mathrm{c}$ & $210.6 \mathrm{ab}$ & $242.6 \mathrm{c}$ & $485.3 \mathrm{c}$ & $540.2 \mathrm{~b}$ & $512.8 \mathrm{c}$ & $0.14 \mathrm{bc}$ & $0.12 \mathrm{c}$ & $0.13 \mathrm{c}$ & $0.10 \mathrm{~d}$ & $0.11 \mathrm{~b}$ & $0.11 \mathrm{c}$ \\
\hline Mean & $377.3 \mathrm{~A}$ & $206.5 B$ & $291.9 B$ & $621.9 \mathrm{~A}$ & $530.2 \mathrm{~B}$ & 576.0A & $0.23 \mathrm{~B}$ & $0.34 \mathrm{~A}$ & 0.28 & $0.19 \mathrm{~B}$ & $0.29 \mathrm{~A}$ & 0.23 \\
\hline $\mathrm{CV}$ & 11.64 & 7.38 & 11.26 & 8.02 & 5.77 & 7.18 & 3.14 & 7.31 & 9.85 & 6.54 & 11.76 & 10.64 \\
\hline Lsd & 120.43 & 41.81 & 40.27 & 136.72 & 83.89 & 50.67 & 0.208 & 0.068 & 0.069 & 0.035 & 0.095 & 0.032 \\
\hline F value & $44.60 * *$ & $6.71 *$ & $49.08^{* *}$ & $49.99 * *$ & $21.50 * *$ & $16.41 * *$ & $18.46^{* * *}$ & 583.87 ** & $13.98^{* *}$ & 802.24 ** & $223.5^{* *}$ & $30.85 * *$ \\
\hline
\end{tabular}

\begin{tabular}{|c|c|c|c|c|c|c|}
\hline \multirow{3}{*}{$\begin{array}{c}\text { Populations } \\
/ \\
\text { Locations }\end{array}$} & \multicolumn{6}{|c|}{ Fixed oil rate (\%) } \\
\hline & \multicolumn{3}{|c|}{2013} & \multicolumn{3}{|c|}{2014} \\
\hline & Loc I & Loc II & Average & Loc I & Loc II & Average \\
\hline Burdur & $24.0 \mathrm{~b}$ & $28.0 \mathrm{~b}$ & $26.0 \mathrm{~b}$ & $22.6 \mathrm{c}$ & $26.3 \mathrm{~b}$ & $24.5 \mathrm{c}$ \\
\hline Tokat & $32.0 \mathrm{a}$ & $32.3 \mathrm{a}$ & $32.1 \mathrm{a}$ & $30.3 \mathrm{a}$ & $31.0 \mathrm{a}$ & $30.6 \mathrm{a}$ \\
\hline Usak & $29.3 \mathrm{a}$ & $33.6 \mathrm{a}$ & $32.5 \mathrm{a}$ & $28.6 \mathrm{~b}$ & $32.3 \mathrm{a}$ & $30.5 \mathrm{a}$ \\
\hline Eskisehir & $21.6 \mathrm{~b}$ & $31.3 \mathrm{a}$ & $26.5 \mathrm{~b}$ & $20.6 \mathrm{~d}$ & $30.6 \mathrm{a}$ & $25.6 \mathrm{~b}$ \\
\hline Antalya & $31.3 \mathrm{a}$ & $32.0 \mathrm{a}$ & $31.6 \mathrm{a}$ & $30.2 \mathrm{a}$ & $30.6 \mathrm{a}$ & $30.4 \mathrm{a}$ \\
\hline Mean & $27.6 \mathrm{~B}$ & $31.4 \mathrm{~A}$ & 29.5 & $26.5 \mathrm{~B}$ & $30.3 \mathrm{~A}$ & 28.4 \\
\hline $\mathbf{C V}$ & 4.09 & 3.23 & 3.64 & 1.19 & 2.58 & 2.10 \\
\hline Lsd & 3.10 & 2.78 & 1.31 & 0.86 & 2.15 & 0.73 \\
\hline F value & $49.35^{* *} *$ & $13.00 * *$ & $18.32 * *$ & $621.00^{* *}$ & $26.22 * *$ & $58.74 * *$ \\
\hline
\end{tabular}

These differences among the populations could be explained by the genetic potential of populations, and generally having higher the plant height, the number of branches, the number of capsule and 1000-seed weight in compared to others populations. Usak population is more early than the others (Table 4). Unlike known, early genotypes may be more yield because of its better use of available moisture and they don't coincide to high temperatures in the flowering period. In a study conducted on another plant (wheat) by Ludwig and Asseng (2010) were reported that yield of early genotypes may be higher according to late varieties due to their better use of available moisture in arid and semi-arid climatic conditions. D'Antuono et al. (2002) reported that the major yield limiting factor for Nigella sativa genotypes seemed low vegetative growth and reduce of assimilate supply during the pre-anthesis phase short duration of its vegetative cycle. The results obtained from the study were comparable with Tuncturk et al. (2012) findings, but were lower than those of Karaman (1999), Toncer and Kizil (2004), Tuncturk et al. (2005) and Ozel et al. (2009). These differences were due to probably variations in climatic conditions, agronomic practices, genotype and soil properties. In addition to, environmental conditions during pollination at the first stage of seed set, determine the number of capsule and branche (Sadeghi, 2009). 
Table 4. Harvest times of populations in experiment locations

\begin{tabular}{lllll}
\hline \multirow{2}{*}{ Populations } & \multicolumn{3}{c}{$\mathbf{2 0 1 3}$} & $\mathbf{2 0 1 4}$ \\
\cline { 2 - 5 } & Loc I & Loc II & Loc I & Loc II \\
\hline Burdur & 23.07 .13 & 2.08 .2013 & 26.07 .14 & 07.08 .2014 \\
Tokat & 25.07 .13 & 5.08 .2013 & 29.07 .14 & 10.08 .2014 \\
Usak & 17.07 .13 & 28.07 .2013 & 20.07 .14 & 07.08 .2014 \\
Eskisehir & 25.07 .13 & 5.08 .2013 & 29.07 .14 & 10.08 .2014 \\
Antalya & 23.07 .13 & 5.08 .2013 & 26.07 .14 & 10.08 .2014 \\
\hline
\end{tabular}

Loc 1: Isparta location, Loc 2: Eskisehir location

\section{Yield components}

The plant height, the number of branches, the number of capsule and 1000-seed weight of populations varied according to locations and years. Generally, the tallest plant height was determined in Eskisehir and Tokat populations, the highest numbers of branches and number of capsule were determined in Usak and Tokat populations and the highest 1000-seed weight was obtained from Usak and Burdur populations in both years and locations (Table 3). Considering the locations and years in terms of total precipitation in Table 1, plant height, the number of branches and the number of capsule were statistically higher in rainy locations and years (Table 3). In the study, the number of branches and the number of capsules increased with the elongation of plant height due to rainfall, and seed yield was positively affected increasing yield components. Ghamarnia and Jalili (2013) reported that black cumin is a medicinal plant sensitive to water stress. The same authors stated that seed yield and its components were decreased rapidly according to increased of water stress during growing periods under semi-arid climatic conditions. Sadeghi (2009) reported that there was a positive correlation between seed yield and aboveground biomass. Ozguven and Sekeroglu (2007) and Tuncturk et al. (2012) stated that yield components such as the number of branches and capsules affects directly seed yield in the black cumin (Ozguven and Sekeroglu, 2007; Tuncturk et al., 2012) .

\section{Essential oil content}

The essential oil content of black cumin populations in Isparta and Eskisehir locations are presented in Table 3. In the research, population, location and population $\mathrm{x}$ location interaction were found significant. No significant differences between the years were found (Table 3 ).

The essential oil content of the years was found to be very close to each other with $0.28 \%$ in the first year and $0.23 \%$ in the second year (Table 3 ).

In both years (2013 and 2014), the mean essential oil content $(0.34 \%$ and $0.29 \%$, respectively) in Eskisehir location was higher than Isparta location $(0.23 \%$ and $0.19 \%$, respectively).

In compared to populations, the highest essential oil content was obtained from Tokat population in both years and locations. The essential oil wasn't obtained from Usak population (Table 3).
The mean essential oil content in population $\mathrm{x}$ location interaction varied between $0.13-0.64 \%$ in 2013 and 0.11 $0.58 \%$ in 2014 .

Most researchers stated that the essential oil composition of black cumin varied depending on the genotype of the plant, growing, climatic and environmental conditions as well as distillation method (Ozguven and Tansi, 1989; Toncer and Kizil, 2004; Tuncturk et al., 2005; Ozel et al., 2009; Matthaus and Ozcan, 2011). Lei (2004) reported that the essential oil ratio of some essential oil plants was decreased in high rainfall and humidity conditions.

Our results agree with findings of the researchers who reported that essential oil varied between $0.36 \%$ and 0.49\% (Ozguven and Tansi, 1989; Geren et al., 1997), $0.27 \%$ and $0.35 \%$ (Toncer and Kizil, 2004), $0.48 .0 \%$ and $0.51 \%$ (Tuncturk et al., 2005), $0.01 \%$ and $0.50 \%$ (Ozel et al., 2009) and $0.28 \%$ and $0.36 \%$ (Matthaus and Ozcan, 2011)

\section{Fixed oil rate}

In term of fixed oil rate, population, location and population $\mathrm{x}$ location interaction were found significant. No significant differences between the years were found (Table 3).

The fixed oil rate of years was found to be very close to each other with $29.5 \%$ in the first year and $28.4 \%$ in the second year (Table 3).

In compared to locations, average fixed oil rate of Eskisehir location (31.4\% and $30.3 \%$, respectively) was higher than Isparta location $(27.6 \%$ and $26.5 \%$, respectively) in both 2013 and 2014 (Table 3).

In compared to populations, the highest fixed oil rate was obtained from Tokat and Usak populations in the both years and locations.

The mean fixed oil rate in population $\mathrm{x}$ location interaction varied between $26.0 \%$ and $32.5 \%$ during 2013 and $24.5 \%$ and $30.6 \%$ during 2014.

Many researchers determined that the fixed oil of black cumin vary between $30.4 \%$ and $36.4 \%$ (Sener et al., 1985; Matthaus and Ozcan, 2011). Ustun et al. (1990) reported that the oil contents of black cumin seeds collected from the Kutahya, Denizli and Konya provinces were $24.4 \%, 29.5 \%$, and $29.7 \%$, respectively. Our results are similar with the findings of the above-mentioned researchers. The differences between seed oil fixed oil rate 
can be probably due to genotype, growing, localities, climatic and environmental conditions (Sener et al., 1985; Ustun et al., 1990; Matthaus and Ozcan, 2011; Hendawy et al., 2012).

\section{CONCLUSION}

The results obtained from present study indicated that locations (Isparta and Eskisehir) had significant effects on seed yield, some yield components, essential oil and fixed oil contents of black cumin populations. While yield components of black cumin populations varied according to locations and years, seed yield was higher in Isparta location on all populations due to higher rainfall than Eskisehir. Of the average of locations, the highest seed yield was determined in Usak population, followed by Eskisehir population. But, it was not detected essential oil in Usak population. The highest essential oil content was obtained from Tokat population in both locations and years. Tokat, Usak and Antalya populations on fixed oil rate were in the same statistical group at the $\mathrm{P}<0.01$ level on the basis of the LSD test.

Based on the results of the research: Tokat and Eskisehir populations for high seed yield, essential oil and fixed oil contents, and Usak population for high seed yield and fixed oil content could be evaluated in the breeding programme for line and cultivar development.

\section{LITERATURE CITED}

Akgul, A. 1993. Spices Science and Technology. Puplication of Food Technology Society. No:15, 451p., Ankara. (in Turkish).

Baytop, T. 1984. Therapy with Medicinal Plants in Turkey. p. 480 (Past and Present). Publications of the Istanbul University. No.3255, Istanbul. (in Turkish).

D'Antuono, LF., A. Moretti and FS. Antonio. 2002. Seed yield, yield components, oil content and essential oil content and composition of Nigella sativa L. and Nigella damascena L. Industrial Crops and Products. 15: 59-69.

Geren, H., E. Bayram and A. Ceylan. 1997. Effect of different sowing dates and phosphorus fertilizer application on the yield and quality characteristics of black cumin (Nigella sativa L.). Proceedings of the Second National Field Crops Congress. pp: 376-380.

Ghamarnia, H. and Z. Jalili. 2013. Water stress effects on different black cumin (Nigella sativa L.) components in a semi-arid region. Int. J. of Agronomy and Plant Production. 4 (4):753-762

Hendawy, SF., SE. El-Sherbeny, MS. Hussein, KA. Khalid and GM. Ghazal. 2012. Response of two species of black cumin to foliar spray treatments. Australian J. of Basic and Applied Sciences. 6(10): 636-642.

Kar, Y., N. Sen and Y. Tekeli. 2007. Investigation of black cumin (Nigella sativa L.) seeds cultivated in region Samsun and country of Egypt in terms of antioxidant activity. Suleyman Demirel University J. of Science. 2(2): 197-203.

Karaman, A. 1999. A research on effect of different sowing dates on seed yield and quality of black cumin (Nigella damascena L.). Institute of Natural and Applied Sciences, University of Cukurova, M.Sc. Thesis, p: 41 Adana, Turkey. (in Turkish).
Lei, Y. 2004. Research on the introduction and transplanting of aromatic plants from the mediterranean region to Heshuo Xinjiang and Shanghai China. In: Future for Medicinal and Aromatic Plants (Eds.L.E. Craker et al.), Acta Horticulture China. 629: 261-271.

Ludwig, F. and S. Asseng. 2010. Potential benefits of early vigor and changes in phenology in wheat to adapt to warmer and drier climates. Agriculture Systems. 103: 127-136.

Matthaus, B. and MM. Ozcan. 2011. Fatty Acids, tocopherol, and sterol contents of some Nigella species seed oil. Czech J. Food Science. 29(2): 145-150.

Nergiz, C. and S. Otles. 1993. Chemical composition of Nigella sativa L. seeds. Food Chemistry. 48: 259-261.

Ozel, A., U. Demirel, I. Guler and K. Erden. 2009. Effect of different row spacing and seeding rate on black cumin (Nigella sativa L.) yields and some agricultural characters. Harran Uni. J. of Agriculture Faculty. 13(1): 17-25. (in Turkish).

Ozguven, M. and S. Tansi. 1989. A study on determination of optimal sowing dates of Nigella species at Cukurova conditions). In: Proc. VII ${ }^{\text {th }}$ Sym. on Plant Originated Crude Drugs, 19-21 May 1989, Istanbul.

Ozguven, M. and N. Sekeroglu. 2007. Agricultural practices for high yield and quality of black cumin (Nigella sativa L.) cultivated in Turkey. Acta Horticulturae. 756:329-337.

Sadeghi, S., A. Rahnavard and ZY. Ashrafi. 2009. Study importance of sowing date and plant density affect on black cumin yield. Botany Research International. 2(2): 94-98.

Sener, B., S. Kusmenoglu, A. Mutlugil and F. Bingol. 1985. A study with the seed of Nigella sativa. Gazi Uni. J. of Pharmacy Faculty. 2(1): 1-8.

Stainier, C. 1975. Role and functions of the European Pharmacopoeia. Ann Ist Super Sanita. 11(3-4): 211-219.

Sultan, MT., MS. Butt, FM. Anjum, A. Jamil, S. Akhtar and M. Nasir. 2009. Nutritional profile of indigenous cultivar of black cumin seeds and antioxidant potential of its fixed and essential oil. Pakistan J. Botany. 41: 32-40.

Toncer, O. and S. Kizil. 2004. Effect of seed rate on agronomic and technologic characters of Nigella sativa L. International J. of Agriculture \& Biology. 3: 529-532.

Tuncturk, M., Z. Ekin and D. Turkozu. 2005. Response of black cumin (Nigella sativa L.) to different seed rates growth, yield components and essential oil. J. of Agronomy. 4(3): 216-219.

Tuncturk, R., M. Tuncturk and V. Ciftci. 2012. The effects of varying nitrogen doses on yield and some yield components of black cumin (Nigella sativa L.). Advances in Environmental Biology. 6(2): 855-858.

Ustun, G., L. Kent, N. Cekin and H. Civelekoglu. 1990. Investigation on the technological properties of Nigella sativa (black cumin) seed oil. J. American Oil Chemical Society. 67: 958-960.

Yasar, S. 2005. Determination of fixed and essential oil contents and soil characteristic of some perennial medical plants that grow naturally in the campus of Cukurova University. Department of Biology Institute of Natural and Applied Sciences University of Cukurova. MSc Thesis, 43p, Adana. (in Turkish)

Yilmaz, G. 2008. New approaches in growing of medicinal and aromatic plants. Graduate Course Notes (unpublished). Gaziosmanpasa University Agriculture Faculty, Field Crops, Tokat. (in Turkish). 